\title{
触 New Disease Reports \\ First detection of Raspberry ringspot virus in mosaic diseased hybrid roses in Germany
}

\author{
S. von Bargen*, R. Demiral and C. Büttner
}

Humboldt-Universität zu Berlin, Department of Crop and Animal Sciences, Division Phytomedicine, Lentzeallee 55/57, 14195 Berlin, Germany

*E-mail: susanne.von.bargen@agrar.hu-berlin.de

Received: 01 Sep 2015. Published: 07 Nov 2015. Keywords: ELISA, TEM, RT-PCR, Nepovirus

Roses (Rosa hybrida) cultivated for several years at the Isle of Mainau, Lake Constance, Germany developed mosaic, leaf chlorosis, vein netting and stunting (Fig. 1a). Various diseased rose cultivars such as Escimo, Diamant, Leonardo da Vinci, Chippendale, Trier 2000, Innocencia, Kurfürstin Sophie, and Alea were sampled in the summer of 2014 Symptoms suggested rose mosaic disease (RMD) that is caused by infection with any of a number of different viruses. The most prevalent virus species associated with RMD occurring worldwide are members of the ilar- and nepoviruses such as Prunus necrotic ringspot virus (PNRSV), Apple mosaic virus (ApMV), and Arabis mosaic virus (ArMV) (Horst \& Cloyd, 2007) None of these viruses could be detected by DAS-ELISA in bud and leaf samples of eight diseased roses.

Mechanical inoculation of Chenopodium quinoa, Nicotiana benthamiana, and $N$. tabacum cv. Samsun with homogenates of buds and leaves from four out of eight rose samples with stunting and leaf chorosis produced systemic mottle, curling and deformation of leaves in $N$. benthamiana. In $C$. quinoa chlorotic ringspots on primarily infected leaves were induced followed by systemic leaf chlorosis and necrosis of the shoot tip (Fig. 1b). In $N$. tabacum cv. samsun no symptoms could be observed until three weeks post inoculation. Additionally, no symptoms were induced in test plants inoculated with material from symptomless roses serving as negative controls. Isometric particles with a diameter of approximately $28 \mathrm{~nm}$ were observed by electron microscopy in dip preparations of leaf homogenates from symptom-bearing test plants (Fig. 2). Induced symptoms in test plants and particle morphology suggested an infection with a nepovirus. Therefore, RT-PCR was carried out according to Wei \& Clover (2008) applying two different primer pairs specific for the amplification of a RNA1 fragment (RNA-dependent-RNA-polymerase (RdRp) coding region) of nepoviruses of subgroup A and B, respectively. Specific PCRproducts were obtained from symptom-bearing rose samples as well as from respective experimental hosts displaying virus-specific symptoms.

Purified RdRp-fragments amplified from three rose samples were sequenced from both directions (EMBL-EBI Accession Nos. LN877215-LN877217) and subjected to BLASTN analyses revealing highest identities (88-89\%) to a grapevine isolate of Raspberry ringspot virus (RpRSV) from Germany (AY310444). We performed a RpRSVspecific RT-PCR using an RNA2-targeted primer pair amplifying a part of the movement protein (MP) coding region (Ochoa-Corona et al., 2005) to validate the infection of roses with RpRSV. The presence of the virus could be confirmed by RT-PCR amplification of the RpRSV-specific 385 bp MPfragment in samples derived from five different roses (cvs. Alea, Escimo, Kurfürstin Sophie, Leonardo da Vinci, Trier 2000), all exhibiting stunting, mosaic and/or chlorotic vein netting (Fig. 3). Sequencing and BLASTN analyses of selected RpRSV-MP fragments (LN877218-LN877222) revealed maximal $90 \%$ nucleotide identity to the corresponding region of the grapevine strain of RpRSV (AY310445). This is the first report of RpRSV in tea hybrid roses exhibiting mosaic, chlorotic vein netting and stunting. As no other isometric viruses previously known to be associated with RMD were detected in the symptomatic roses, it is assumed that RpRSV can induce a similar disease in investigated cultivars.

\section{Acknowledgements}

We thank the Mainau $\mathrm{GmbH}$ for permission to publish results and $\mathrm{G}$. Buddruss, A. Klinke and R. Junge for excellent technical assistance.

\section{References}

Horst RK, Cloyd RD, eds, 2007. Compendium of Rose Diseases and Pests, Vol. 2. St Paul, MN, USA: American Phytopathological Society, APS Press.

Ochoa-Corona FM, Lebas BSM, Tang J, Bootten TJ, Stewart FJ, Elliott DR, Alexander BJR, 2005. Diagnosis and strain typing of Pepino mosaic virus and Raspberry ringspot virus by RT-PCR and SSCP. The 15th Biennial Australasian Plant Pathology Society Conference, 26-29 September 2005, Geelong, Victoria, Australia. Conference Handbook, 259. Wei T, Clover G, 2008. Use of primers with $5^{\prime}$ non-complementary sequences in RT-PCR for the detection of nepovirus subgroups A and B. Journal of Virological Methods 153, 16-21.

http://dx.doi.org/10.1016/j.jviromet.2008.06.020

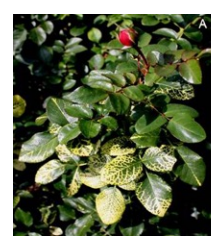

Figure 1

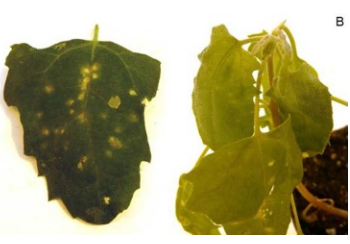

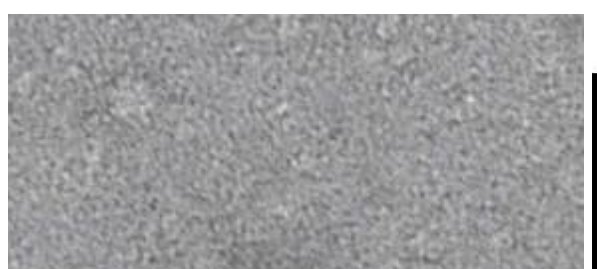

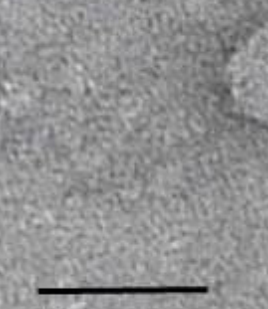
$50 \mathrm{~nm}$
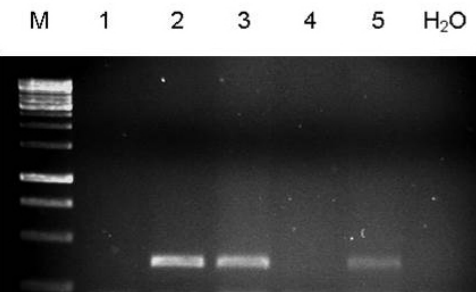

$-385 \mathrm{bp}$

Figure 3

To cite this report: von Bargen S, Demiral R, Büttner C, 2015. First detection of Raspberry ringspot virus in mosaic diseased hybrid roses in Germany. New Disease Reports 32, 18. http://dx.doi.org/10.5197/j.2044-0588.2015.032.018

(c) 2015 The Authors

This report was published on-line at www.ndrs.org.uk where high quality versions of the figures can be found. 